\title{
Guiding e-learning: introducing online informal learning to a global voluntary organisation
}

Article

Other

This is the pre-peer review submitted version; no changes were made to later versions after peer review

Williams, S., Spiret, C., Dimitriadi, Y. and McCrindle, R. (2013) Guiding e-learning: introducing online informal learning to a global voluntary organisation. British Journal of Educational Technology, 44 (2). E39-E41. ISSN 1467-8535 doi: https://doi.org/10.1111/j.1467-8535.2012.01361.x Available at https://centaur.reading.ac.uk/28981/

It is advisable to refer to the publisher's version if you intend to cite from the work. See Guidance on citing.

To link to this article DOI: http://dx.doi.org/10.1111/j.1467-8535.2012.01361.x

Publisher: Wiley

All outputs in CentAUR are protected by Intellectual Property Rights law, including copyright law. Copyright and IPR is retained by the creators or other copyright holders. Terms and conditions for use of this material are defined in the End User Agreement.

www.reading.ac.uk/centaur 


\section{CentAUR}

Central Archive at the University of Reading

Reading's research outputs online 


\section{Guiding e-learning: introducing online informal learning to a global voluntary organisation}

\section{Introduction}

The World Association of Girl Guides and Girl Scouts (WAGGGS) is the umbrella organisation for Member Organisations from 145 countries around the world, with a total membership of ten million. While Member Organisations offer training and development within their own countries, WAGGGS offers international opportunities. For example, WAGGGS offers opportunities for leadership development at international locations where a group of facilitators (typically five) facilitate the learning of a group of thirty participants during a week-long event, when possible interpreters are provided. These events are widely lauded but are only available to a few, many potential participants cannot afford to travel, or get the necessary permissions. In addition the volunteer facilitators have limited time for travel and attending events. This project seeks to explore how technology can be used to offer similar opportunities to those provided by the face-to-face courses to a much wider audience, while retaining the community and interactive learning aspects of the existing programmes.

Technology changes the way in which communities come together, (Wenger, White, \& Smith, 2009); however not everyone is at ease with technology and degrees of digital literacy vary (Hargittai, 2005). Technology was expected to create a revolution in education by providing access across the globe (Friedman, 2005; Liyanagunawardena, Adams, Rassool, \& Williams, 2011). The reality is that introducing technology into education is always challenging (Collins \& Halverson, 2010).There are concerns that this may further marginalise the deprived (Carr-Chellman, 2005), many factors impact on participants ability to persevere with an online course (Lee, Choi, \& Kim, 2012). With the international prevalence of social network sites, such as Facebook and Twitter, people are becoming comfortable contributing in online places, however in pedagogic situation there continues to be a "lurker" role (Arnold \& Paulus, 2010; Dennen, 2008).

In this paper the authors report their experiences of the first trial run of an international online course and discuss the issues as they prepare for the next run.

\section{The Prototype Course}

Initial research (Williams, Spiret, Dimitriadi, \& McCrindle, 2012) had indicated there is a high use and appreciation of technology within the organisation, across ages, cultures and languages. However, there is not equal access to technologies, technological capabilities of members varies around the world and within 
neighbourhoods, and for some obtaining connectivity to the Internet is challenging.

For the prototype course built to test the concepts, it was determined that:

- the platform Moodle ${ }^{\mathrm{TM}}$ would be used for delivery;

- the course would be three weeks, with three days pre-activities;

- the course would be run in English, removing translation overheads;

- participants should reflect the spread and diversity of WAGGGS;

- there should be twenty participants;

- the facilitation would be undertaken by staff associated with the project.

The course itself was designed to require participants to engage in individual and group tasks, with support from discussion forums.

The five international regions of WAGGGS were asked to identify four participants each. At the start of the course there were nineteen nominated participants from: Australia (2), Bahamas, Denmark (2), Egypt, Kenya (2), Mexico, Singapore (2), Slovenia (2), South Africa (2), Tunisia, United Arab Emirates, Venezuela, USA.

\section{Reflections on the course}

Participants were asked to complete a survey at the start and the end of the course, engagement was observed along with materials accessed; the following qualitative and quantitative based reflections are drawn from this data.

Of the nineteen nominated participants three never logged in, and two did not complete the course. The three who did not log in have never responded to communications, so no data for them is available. The two who dropped out had indicated on the initial survey that they were very busy with competing demands on their time within their volunteer role in the organisation and beyond. Five were very active throughout, and the majority (nine) participated spasmodically. Eight had previously tried or used e-learning, the remainder had not used it but had observed others using it. Four of the five most active participants had elearning experience. The participants were all over the specified minimum age of eighteen, with eleven under 30 and five over 40 (none were between 30 and 40). There was no discernable pattern of engagement linked to age group.

At the end of the course participants reported a variety of work patterns, with different working practices at weekends compared to weekdays. Some participants logged on more than once a day while members of the spasmodic users group logged on a few times per week. Some reported that they had experienced difficulties accessing the Internet during the course due to both short-term and longer-term issues. There was a lot of discussion about time zones, particularly when daylight-saving clock-altering occurred in some locations during the course, sending some participants' clocks forward and others back. Group working suffered as a result of these temporal and access challenges, with the week allocated for a task hardly allowing some groups time to exchange messages agreeing roles. 
Most considered that they had good or fluent English, however two initially indicated poor English skills, finally these two and one other, indicated that they had experienced difficulties with the use of English. Other non-native English speakers indicated that during the course they used a variety of approaches to overcome language difficulties including the use of online translators, although there was some scepticism about the quality of translations.

The majority of the participants who completed the course reported that they had enjoyed the experience and that they would sign up for another, only one participant rated the course below satisfactory, this participant also indicated language difficulties.

\section{Discussion and Conclusion}

This was the first of a series of studies, further exploration is necessary before designs can be finalised. The general positive response is heartening, but the participants were all drawn from an organisation with a supportive ethos, and so it is important not to ignore the issues raised.

In face-to-face events cohort sizes are dictated by accommodation and costs, as well as pedagogic needs. Participants are disengaged from their day-to-day lives and fully committed to the course. Facilitators are able to instantly adapt content as needed, participants who experience language difficulties are sometimes supported by interpreters (for a limited number of languages) and always supported by the community. With online events the parameters and environments are different, in particular participants remain in their own locations around the world with all the commitments of day-to-day life. Open questions that need to be considered include:

- How large should a cohort be?

- How should participants be identified?

- How much time should participants be expected to commit per day/week?

- Should lurking be acceptable?

- How can those who can only connect occasionally be catered for?

- How can group work be facilitated?

- How can temporal differences be accommodated?

- How can the language problems be overcome?

This study contributes to understanding how individuals within a global voluntary organisation react and interact with online informal learning. The work here has informed the design of the next trial course.

\section{Acknowledgements}

This work is part of a Knowledge Transfer Partnership (KTP) project between the University of Reading and the World Association for Girl Guides and Girl Scouts (WAGGGS) with funding from the Economic \& Social Research Council and the Technology Strategy Board. The team are grateful to the UPS Foundation who provided generous support to WAGGGS to allow them to participate in this 
work. We are grateful to Lydia Mature, Jenny Berrisford and other members of

WAGGGS for their support with the project.

\section{References}

Arnold, N., \& Paulus, T. (2010). Using a social networking site for experiential learning: Appropriating, lurking, modeling and community building. The Internet and Higher Education, 13(4), 188-196.

Carr-Chellman, A. A. (2005). Introduction. In A. A. Carr-Chellman (Ed.), Global Perspectives on E-Learning: Rhetoric and Reality (1-13). Thousand Oaks: Sage.

Collins, A., \& Halverson, R. (2010). The second educational revolution: rethinking education in the age of technology. Journal of Computer Assisted Learning, 26(1), 18-27.

Dennen, V. (2008). Pedagogical lurking: Student engagement in non-posting discussion behavior. Computers in Human Behavior, 24(4), 1624-1633.

Friedman, T. L. (2005). The World Is Flat: A Brief History of the 21st Century. New York: Farrar, Strauss and Giroux.

Hargittai, E. (2005). Survey Measures of Web-Oriented Digital Literacy. Social Science Computer Review, 23(3), 371-379.

Lee, Y., Choi, J., \& Kim, T. (2012). Discriminating factors between completers of and dropouts from online learning courses. British Journal of Educational Technology. Online: doi: 10.1111/j.1467-8535.2012.01306.x

Liyanagunawardena, T. R., Adams, A. A., Rassool, N., \& Williams, S. (2011). Extending Higher Educational Opportunities through e-Learning: A Case Study from Sri Lanka. In: 1st International Australasian Conference on Enabling Access to Higher Education Adelaide, South Australia 2011: 291301.

Wenger, E., White, N., \& Smith, J. D. (2009). Digital Habitats. Portland: CPsquare.

Williams, S., Spiret, C., Dimitriadi, Y., \& McCrindle, R. (2012). Auditing Technology Uses within a Global Voluntary Organisation. In: Global TIME: Global Conference on Technology, Innovation, Media \& Education. Online: AAEC; 2012: 104-109. 